\title{
The Role of Information Technology in Fintech Innovation: Insights from the European Fintech Ecosystem
}

\author{
Stanislav Mamonov \\ Montclair State University \\ stanislav.mamonov@montclair.edu
}

\begin{abstract}
Fintech is an active area of innovation and a rapidly growing sector of the economy, yet relatively little is known about how information technology contributes to innovation in fintech. We draw on the business model canvas framework and we examine the role of information technology in the business models of leading European fintech startups. We find that information technology plays a key role across nearly all components of the fintech business models that we reviewed, orchestrating resources and processes to efficiently deliver personalized financial services to customers. Focusing on the IT-enabled value propositions across the fintech startups in our sample, we find that the startups tend to emphasize low-cost offerings that may pose a threat to incumbent business models in financial services.
\end{abstract}

\section{Introduction}

Disruptive innovations are a common concern for established firms [11]. Disruptive innovations introduce significant changes in the value creation process within established industries by either developing new markets or changing the existing value creation networks [6]. In many cases, such innovations may initially target less profitable segments of the market, but evolve into dominant business models within the respective industries disrupting the incumbent firms [41].

Fintech, defined as design and delivery of financial products and services through technology [25], is one of the most active areas of startup innovation. KPMG reports that global fintech investments reached $\$ 135.7$ billion in 2019 [23] and forecasts for the global fintech market suggest that fintech revenues will reach $\$ 300$ billion by 2023 [26]. Despite the practical importance of the fintech market, there has been relatively little academic research on how startups leverage technology in this market and how information technology (IT) may contribute to the disruption of traditional business models in financial services [17].

To address this gap in research, we draw on the business model canvas literature [30] and we examine the key technology-enabled innovations offered by the leading European fintech startups. KPMG reports that European fintech investments totaled $\$ 64.2$ billion in 2019 accounting for $42.8 \%$ of the global fintech investments [23].

This study is a part of a broader research stream exploring the role of technology in innovation. Here, we seek to address the following research questions: 1) How does IT contribute to innovation in fintech? and 2) What types of IT-enabled innovations are likely to disrupt existing financial services? To address these questions, we focus on the leading startups in the European fintech ecosystem based on the funds raised from investors in the past six years and we examine how IT contributes to value creation within each product or service offering. We also evaluate the likely disruptive impact of the IT-enabled innovations.

Our analysis reveals that information technology is deeply interwoven into nearly all components of the fintech startup business models in our sample. IT plays a dual role of serving as the customer facing artifact in service delivery, and it is also a key coordination mechanism that orchestrates all business processes within the respective companies. Focusing on value propositions offered by the fintech startups in our study, we find that the majority emphasize low-cost alternatives to traditional financial services, thus posing a potential disruption threat to the incumbent firms in the respective markets.

\section{Empirical and theoretical background}

\subsection{The role of technology in innovation}

The connection between technology and innovation is a rich area of research $[13,39]$ and a full review of this literature is beyond the scope of the current study. Here, we briefly review the key themes that are relevant to our work.

Information technology is broadly acknowledged as an important element of internal process optimization $[28,36]$, as well as new product and new service development [28]. Whereas much of the earlier work on 
the impact of IT investments focused on the macro level outcomes, e.g. firm survival and firm revenue [37], more recent research has shown that the effects of IT go beyond increasing operational efficiencies. Mithas et al. [28] have shown the IT investments increase new product and new service introductions, demonstrating that IT investments have a positive effect on innovation within established firms.

Several scholars suggested that information technologies fundamentally alter the innovation process and require novel organizing logics designed to capitalize on the core benefits of digital technologies [29, 40]. Open innovation, i.e. engagement of external parties in the innovation process, emerged as a dominant theme in the discussions on the role of IT in innovation [13]. Open innovation encompasses supplier-side, as well as customer-side innovation. Value co-creation is an important area in customer-driven product and service innovation $[4,18]$.

\subsection{Fintech}

Although a number of competing definitions of fintech have been proposed [27], we adopt the following definition in our study. Fintech is defined as design and delivery of financial products and services through technology [25]. Financial services encompass a broad range of services that include payments, wealth management, lending, capital markets and insurance among others [24].

An economic analysis of financial services has revealed that despite digitization and adoption of novel technology-supported business services in finance, the industry as a whole has shown little in the way of increasing overall efficiency and the cost of financial intermediation remained stable over time at roughly $2 \%$ of GDP [31]. The perceived lack of efficiency in financial services industry has spurred many startups in the fintech domain and their efforts have generally focused on disintermediation and automation [5]. Industry surveys suggest that novel fintech offerings may be particularly appealing to young, high-income, high-value customers [11].

Although the research on fintech is just beginning to emerge, there have been several attempts to develop general taxonomies of fintech innovations. Focusing on the services offered by the companies, Lee and Shin [24] suggested that all fintech startups belong to one of the following categories: payments, wealth management, crowdfunding, lending, capital markets and insurance. Focusing on the technical capabilities, Gai et al. [12] proposed that technical innovations in fintech can be characterized as innovations in authentication and control, risk management, data usage, risk detection, and data storage and processing. Examining innovations in the insurance industry, Szopinski et al. [34] suggested that innovations fall into infrastructure, service, or network promotion related categories.

Although prior research contains several fintech taxonomies [12, 24, 34], they do not address the question of how information technologies affect fintech business models. In the next section, we discuss the business model canvas framework $[1,42]$ that provides the theoretical foundation for the examination of the role of IT in fintech business model innovation in our study.

\subsection{Business model canvas and business model disruptions}

Business model innovation has been long recognized as an important element of business strategy $[1,42]$. Business model canvas emerged as a pragmatic framework focused on defining the key components of a business model with the goal of identifying opportunities for business model innovation [30]. Business model canvas suggests that identification of the 1) key partners, 2) key activities, 3) value proposition, 4) customer relationships, 5) customer segments, 6) key resources and 7) distribution channels can lead to reassessment of the current state and identification of novel options within each of the components that can pave the way to business model innovation.

Disruptive innovation theory emerged from the observation that many dominant firms often fall victim to innovations that the firms dismiss at the time of the innovation introduction [6]. For example, IBM famously dismissed the personal computer market opportunity early on [19], and it had to play catchup to the early movers in the market. Christensen's theory of disruptive innovation [6] highlights the fact that ignoring innovative offerings in emergent markets often makes economic sense to the incumbent firms, thus highlighting a fundamental impediment to innovation within the incumbent firms.

The focus of the current study is on understanding how fintech startups leverage IT to produce innovations within the components of the business models and to understand when such innovations may produce disruptions in the incumbent business models. In the next section, we discuss the methodology in our study.

\section{Methodology}

Methodologically, we take on a pragmatic stance that emphasizes the connection to the real world [16]. 
We follow a multi-case methodology [10] to assess and contrast observations across a theoretically based [15] sample of fintech startups.

\subsection{Sample selection}

Our analysis is focused on the European market because industry reports indicate that $42.8 \%$ of total global fintech investments are made in the European startups reflecting the dynamic innovative nature of this market.

We relied on Crunchbase [9] to identify fintech startups headquartered in Europe. Crunchbase collates information on over 5000 startups across the globe in different sectors of the economy. We filtered Crunchbase listings for "fintech" as the category and "Europe" as the headquarters location. We further limited our search to active startups that were founded in the period 2014-2020.

We obtained a list of fintech startups headquartered in Europe that included 1903 companies. Many of the startups on the list are in the early stages of development. $95 \%$ of the startups received only a single round of financing and therefore the long-term prospects of these companies are less certain [3]. Historical trends suggest that less than $12 \%$ of venture capital (VC) investments lead to successful exits [14]. Because the focus of our analysis is on the effects of IT on business model innovation in fintech, we decided to focus our analysis on the startups that progressed to at least the second round of fundraising (typically a series B) and raised at least $\$ 150$ million dollars in total funding. We excluded one company - Finleap - from our analysis because Finleap is effectively a venture capital (VC) investment firm that holds investments in a number of other fintech firms. The resultant list contains thirteen companies that collectively raised over $\$ 5.2$ billion. Investments in these firms accounted for $52.7 \%$ of total $\mathrm{VC}$ investments in the European fintech firms over the 2014-2020 period.

\subsection{Analytical methodology}

In our analysis on the role of technology in innovation we focused on how IT affects the key components of the business model canvas. We examine the questions outlined in Table 1 below within the analysis of each component [30].

Table 1. Startup value proposition, business model type, market focus and funding raised

\begin{tabular}{|l|l|}
\hline $\begin{array}{l}\text { Value } \\
\text { proposition }\end{array}$ & $\begin{array}{l}\text { What is the role of IT in the value } \\
\text { proposition of each company? }\end{array}$ \\
\hline
\end{tabular}

\begin{tabular}{|l|l|}
\hline $\begin{array}{l}\text { Customer } \\
\text { segments and } \\
\text { distribution } \\
\text { channels }\end{array}$ & $\begin{array}{l}\text { How does IT enable the company } \\
\text { to address different customer } \\
\text { needs? } \\
\text { How does IT facilitate/enable } \\
\text { different distribution channels? }\end{array}$ \\
\hline Key activities & $\begin{array}{l}\text { How is IT involved in the key } \\
\text { activities associated with value } \\
\text { delivery? }\end{array}$ \\
\hline Key resources & $\begin{array}{l}\text { How is IT involved in the } \\
\text { acquisition/development of key } \\
\text { resources associated with value } \\
\text { creation/delivery? }\end{array}$ \\
\hline Key partners & $\begin{array}{l}\text { How is IT involved in managing } \\
\text { relationships with key partners? }\end{array}$ \\
\hline Revenue stream & $\begin{array}{l}\text { What are the sources of revenue } \\
\text { for the company? }\end{array}$ \\
\hline
\end{tabular}

To assess the key value proposition, customer segments and distribution channels, key activities, resources, partners and revenue streams, we reviewed the respective company web sites and news announcements. We used NVivo version 12 software to code the collected documents for the components of the business canvas model as well as the role of IT in the respective components.

\section{Results}

The startups in our sample have collectively raised $\$ 5.2$ billion. The mean amount of funding raised is $\$ 400.2$ million and the median is $\$ 275.7$ million. OrkNorth raised $\$ 1.041$ billion, putting it in the lead in terms of total fundraising. Qonto, a small and medium size business (SMB) oriented online bank based in Paris, France, raised the lowest amount of funding in our sample - the company raised $\$ 151.5$ million.

Geographically, we find a concentration of fintech startups in London, UK. Seven of thirteen companies (53.8\%) are based in London and they raised $68.4 \%$ of total funding in our sample. Berlin and Paris each hosts two startups in our sample. The two remaining startups are based in Durham, UK and Zug, Switzerland.

Focusing on the core value proposition, we find that the startups in our sample offer a fairly broad spectrum of financial services. Seven of thirteen companies are in the online/mobile banking services, constituting the largest subgroup in our sample. Three companies in this subgroup focus on consumer banking, three others focus on SMB banking services. The seventh company offers both consumer and SMB banking.

Two companies in our sample offer cash advances and personal loans to consumers, and one company specializes in SMB lending. We also find a company operating an insurance marketplace, a banking 
infrastructure provider, and a cryptocurrency wallet startup in our sample.

Across all firms in our sample, IT platforms and applications are the focal artifacts that deliver value to firms' clients. Mobile apps and backend infrastructure that support business process automation are present across nearly all startups in our sample. OakNorth and SolarisBank are the two exceptions - they both work through intermediaries to introduce their services to end users and therefore these two startups do not have customer facing mobile applications themselves.

We observe a number of different business models in our sample. There are five companies (38.5\%) operating on $\mathrm{B} 2 \mathrm{C}$ models focusing on consumers. We also find four companies $(30.8 \%)$ operating on B2B business models. We find one blended approach executing $\mathrm{B} 2 \mathrm{C}$ alongside $\mathrm{B} 2 \mathrm{~B}$. There are also two companies operating on more complex business models. OakNorth offers a SMB lending platform to banking clients while delivering SMB loans to end customers via partners (B2B2B). Neyber offers personal loans via partnerships with employers (B2B2C).

Focusing on whether the startup offerings represent low-cost alternatives to existing services or entirely new offerings, we find that twelve of thirteen startups $(92.3 \%)$ in our sample are targeting lower price points in the respective markets, whereas only one startup Bancor - is offering novel services. Bancor, aptly named after a universal currency that was proposed by Maynard Keynes [38], is a cryptocurrency wallet that allows cryptocurrency trading. The company is based in Zug, Switzerland. The results are summarized in Table 2 below.

Table 2. Startup value proposition, business model type, market focus and funding raised

\begin{tabular}{|l|l|l|c|c|c|}
\hline Startup & Headquarters & Value proposition & $\begin{array}{l}\text { Market } \\
\text { focus }\end{array}$ & $\begin{array}{l}\text { Model } \\
\text { type }\end{array}$ & $\begin{array}{l}\text { Funding, } \\
\text { mil }\end{array}$ \\
\hline OakNorth & London, UK & SMB lending platform & L & B2B2B & 1041.0 \\
\hline Revolut & London, UK & Consumer online banking services & L & B2C & 902.9 \\
\hline Atom Bank & Durham, UK & Consumer online banking services & L & B2C & 584.4 \\
\hline Monzo & London, UK & Consumer online banking services & L & B2C & 492.8 \\
\hline $\begin{array}{l}\text { Starling } \\
\text { Bank }\end{array}$ & London, UK & Consumer online banking services & L & $\begin{array}{c}\text { B2C and } \\
\text { B2B }\end{array}$ & 476.8 \\
\hline October & Paris, France & SMB banking services & L & B2B & 309.5 \\
\hline Hastee & London, UK & Cash advance & L & B2C & 275.7 \\
\hline $\begin{array}{l}\text { Wefox } \\
\text { Group }\end{array}$ & $\begin{array}{l}\text { Berlin, } \\
\text { Germany }\end{array}$ & Insurance & B2C & 268.5 \\
\hline Neyber & London, UK & Personal loans & L & B2B2C & 198.5 \\
\hline SolarisBank & $\begin{array}{l}\text { Berlin, } \\
\text { Germany }\end{array}$ & $\begin{array}{l}\text { Online banking platform for banks } \\
\text { and fintech startups }\end{array}$ & L & B2B & 178.6 \\
\hline Rapyd & London, UK & SMB banking services & L & B2B & 170.0 \\
\hline Bancor & $\begin{array}{l}\text { Zug, } \\
\text { Switzerland }\end{array}$ & Cryptocurrency wallet & B2C & 152.3 \\
\hline Qonto & Paris, France & SMB banking services & L & B2B & 151.5 \\
\hline
\end{tabular}

L- low cost focus, $\mathrm{N}$ - new market focus

In the next step of the analysis, we examined the role of IT in 1) managing relationships with different customer segments, 2) management of distribution channels, 3) supporting key activities associated with value delivery, 4) provisioning and managing key resources required for product/service delivery, 5) management of relationships with key partners. We also evaluated the key revenue streams for each startup.

\subsection{IT in customer segmentation and service delivery}

Eight of thirteen startups $(61.5 \%)$ in our sample offer online or mobile B2C services. It is not surprising then to find that IT plays a key role in service delivery and customer segmentation. IT systems, commonly a combination of web and mobile applications as well as backend services, are the key artifacts that customers interact with. Customer facing systems also facilitate customer segmentation, i.e. identification of customer groups with distinct needs. For example, the One insurance marketplace offered by Wefox Group assists its customers in finding and evaluating available 
insurance policies and associated costs in different categories of insurance: home, life, auto, etc. The segmentation based on the insurance needs is seamlessly implemented on the website and within the mobile application. Different customer segments navigate the evaluation paths setup to fit specific insurance needs.

\subsection{IT function in service delivery}

Information technology uniformly plays a key role in automating business processes within each startup. For example, online consumer banking services offered by Revolut, Atom Bank, Monzo, and Starling Bank are regulated by the Prudential Regulation Authority (PRA) and Financial Conduct Authority (FCA) in the UK. Online banks are required to comply with anti-money laundering (AML) and know-your-customer (KYC) regulations among other regulatory requirements. The online systems offered by the firms automate account setup for its customers, and they support efficient workflow on the backend associated with AML and KYC regulations. We find similar patterns of frontfacing automation and standardization of back-office operations across other B2C platforms in our sample.

Neyber, which operates on a hybrid B2B2C model, wherein the firm partners with employers and offers personal loans to partners' employees. Neyber solves the channel complexity with encapsulation of the service-related activities in its IT systems that are integrated with employers' payroll and accounting systems. We find a similar pattern of channel management in the case of OakNorth which offers SMB loans via lending partners (B2B2B business model). OakNorth similarly offers system integration to its business partners wherein the loan application and underwriting process can be embedded in the lending partners' systems.

\subsection{IT in coordination/development of key resources}

Focusing on the role of technology in the development and coordination of key resources, we find that the IT systems themselves become the singular most important resource for each of the startups in our sample. The IT systems encompass the customerinterfacing digital artifacts. The IT systems also encapsulate the business logic that underpins the operations of all firms in our sample. For example, October is an online platform that connects SMB owners with potential lenders. The platform standardizes loan application, review and service process while also serving as a critical coordination mechanism bridging borrowers and lenders.

\subsection{IT in management of partner relationships}

We find that many of the startups in our sample are critically dependent on their partners for the key resources required for service delivery. For example, the seven online banks in our sample are dependent on their partnerships with Mastercard that enable them to offer their customers ATM cards that operate across the Mastercard's Maestro platform. The online banks leverage their IT systems to assure seamless integration of online banking services with the Maestro network so that their customers can have access to the funds kept at the banks via the global network of ATMs accessible through Maestro.

We find several other types of dependencies on IT services for integration with the key partners for service delivery. OakNorth, an SMB lending platform, is dependent on seamless integration with its lending partners to facilitate loan applications, underwriting and servicing. Hastee, a provider of cash advance services, is dependent on integration with employers in order to obtain accurate information about earned, but yet unpaid income in order to determine how much it can lend to individual borrowers. Bancor, a cryptocurrency wallet that also enables cryptocurrency conversion, is critically dependent on integration of its system with the leading cryptocurrency exchanges.

\subsection{Revenue models}

We find that startups commonly inherit revenue models from the respective industries in which they operate. For example, WeFox Group collects referral fees for the insurance policies that customers purchase through WeFox's One service. Online consumer and SMB banks charge transaction fees and also earn interest on loans made to their customers. SolarisBank offers software-as-a-service (SaaS) solution to banking institutions and fintech startups, and charges integration and usage fees.

We find that startups in our sample tend to be aggressive in pricing their services. Revolut, Atom Bank, Monzo and Starling Bank offer free accounts and free ATM use, presumably subsidizing these services from other sources.

\subsection{Business model evolution}

Pivots, i.e. changes in the business and business model, are common among early stage startups [33]. We observe this phenomenon in our sample. For example, OakNorth began as an online bank and evolved into a more complex SMB lending platform wherein the company now primarily works through its partner network to reach SMBs that need funding. SolarisBank 
similarly began as an online bank and it pivoted its business model toward a SaaS banking services platform. Revolut began as a narrowly focused crossborder payment solution and it evolved into an online consumer bank that offers a broad spectrum of banking services. The company continues to expand its offerings and it recently launched a trading platform. Neyber, a personal loan app, recently received a banking license and it is expected to develop its offerings to cover a full range of consumer banking services.

Table 3 summarizes the analysis on the role of IT across the key elements of the business models within the business model canvas framework.

Table 3. The role of IT in customer service delivery, key activities, managing relationships with key partners and revenue stream.

\begin{tabular}{|c|c|c|c|c|c|}
\hline Startup & $\begin{array}{l}\text { Customer segment } \\
\text { / Distribution }\end{array}$ & Key activities & Key resources & Key partners & $\begin{array}{l}\text { Revenue } \\
\text { stream }\end{array}$ \\
\hline OakNorth & $\begin{array}{l}\text { Credit analysis and } \\
\text { loan servicing } \\
\text { platform is offered } \\
\text { directly to banks } \\
\text { and other lending } \\
\text { institutions. }\end{array}$ & $\begin{array}{l}\text { Credit analysis } \\
\text { platform supports } \\
\text { SMB loan } \\
\text { underwriting and } \\
\text { loan servicing. }\end{array}$ & $\begin{array}{l}\text { The IT platform } \\
\text { aggregates data } \\
\text { from third } \\
\text { parties, supports } \\
\text { underwriting } \\
\text { analytics and loan } \\
\text { underwriting and } \\
\text { servicing } \\
\text { workflow. }\end{array}$ & $\begin{array}{l}\text { The IT platform } \\
\text { provides the } \\
\text { infrastructure for } \\
\text { collaboration with } \\
\text { banks and other } \\
\text { lending partners. }\end{array}$ & $\begin{array}{l}\text { Interest on } \\
\text { loans. }\end{array}$ \\
\hline Revolut & $\begin{array}{l}\text { Consumer online } \\
\text { banking services } \\
\text { are offered } \\
\text { directly to } \\
\text { consumers via } \\
\text { web and mobile } \\
\text { applications. }\end{array}$ & $\begin{array}{l}\text { Online banking } \\
\text { platform supports } \\
\text { banking, cross- } \\
\text { border payments, } \\
\text { and personal } \\
\text { lending. }\end{array}$ & $\begin{array}{l}\text { Online banking } \\
\text { platform } \\
\text { integrates with } \\
\text { multiple partners } \\
\text { to enable cross- } \\
\text { border transfers } \\
\text { and other } \\
\text { banking } \\
\text { operations. }\end{array}$ & $\begin{array}{l}\text { Online banking } \\
\text { platform integrates } \\
\text { with Mastercard } \\
\text { and several } \\
\text { cryptocurrency } \\
\text { exchanges. }\end{array}$ & $\begin{array}{l}\text { Transaction } \\
\text { fees and } \\
\text { interest on } \\
\text { deposits. }\end{array}$ \\
\hline Atom Bank & $\begin{array}{l}\text { Consumer online } \\
\text { banking services } \\
\text { are offered } \\
\text { directly to } \\
\text { consumers via } \\
\text { web and mobile } \\
\text { applications. }\end{array}$ & $\begin{array}{l}\text { Online banking } \\
\text { platform supports } \\
\text { banking, cross- } \\
\text { border payments, } \\
\text { and personal } \\
\text { lending. }\end{array}$ & $\begin{array}{l}\text { Online banking } \\
\text { platform } \\
\text { integrates with } \\
\text { multiple partners } \\
\text { to enable cross- } \\
\text { border transfers } \\
\text { and other } \\
\text { banking } \\
\text { operations. }\end{array}$ & $\begin{array}{l}\text { Online banking } \\
\text { platform integrates } \\
\text { with Mastercard to } \\
\text { support banking } \\
\text { operations. }\end{array}$ & $\begin{array}{l}\text { Transaction } \\
\text { fees and } \\
\text { interest on } \\
\text { deposits. }\end{array}$ \\
\hline Monzo & $\begin{array}{l}\text { Consumer online } \\
\text { banking services } \\
\text { are offered } \\
\text { directly to } \\
\text { consumers via } \\
\text { web and mobile } \\
\text { applications. }\end{array}$ & $\begin{array}{l}\text { Online banking } \\
\text { platform supports } \\
\text { banking, cross- } \\
\text { border payments, } \\
\text { and personal } \\
\text { lending. }\end{array}$ & $\begin{array}{l}\text { Online banking } \\
\text { platform } \\
\text { integrates with } \\
\text { multiple partners } \\
\text { to enable cross- } \\
\text { border transfers } \\
\text { and other } \\
\text { banking } \\
\text { operations. }\end{array}$ & $\begin{array}{l}\text { Online banking } \\
\text { platform integrates } \\
\text { with Mastercard to } \\
\text { support banking } \\
\text { operations. }\end{array}$ & $\begin{array}{l}\text { Transaction } \\
\text { fees and } \\
\text { interest on } \\
\text { deposits. }\end{array}$ \\
\hline $\begin{array}{l}\text { Starling } \\
\text { Bank }\end{array}$ & $\begin{array}{l}\text { Consumer online } \\
\text { banking services } \\
\text { are offered } \\
\text { directly to } \\
\text { consumers and } \\
\text { businesses via } \\
\text { mobile } \\
\text { applications. }\end{array}$ & $\begin{array}{l}\text { Online banking } \\
\text { platform supports } \\
\text { banking, cross- } \\
\text { border payments, } \\
\text { and personal } \\
\text { lending. }\end{array}$ & $\begin{array}{l}\text { Online banking } \\
\text { platform } \\
\text { integrates with } \\
\text { multiple partners } \\
\text { to enable cross- } \\
\text { border transfers } \\
\text { and other } \\
\text { banking } \\
\text { operations. }\end{array}$ & $\begin{array}{l}\text { Online banking } \\
\text { platform integrates } \\
\text { with Mastercard to } \\
\text { support banking } \\
\text { operations. }\end{array}$ & $\begin{array}{l}\text { Transaction } \\
\text { fees and } \\
\text { interest on } \\
\text { deposits. }\end{array}$ \\
\hline
\end{tabular}




\begin{tabular}{|c|c|c|c|c|c|}
\hline October & $\begin{array}{l}\text { The online SMB } \\
\text { lending platform } \\
\text { connects lenders } \\
\text { with businesses } \\
\text { seeking funding. }\end{array}$ & $\begin{array}{l}\text { Online lending } \\
\text { platform supports all } \\
\text { aspects of loan } \\
\text { underwriting and } \\
\text { loan management. }\end{array}$ & $\begin{array}{l}\text { Online platform } \\
\text { offers ready } \\
\text { access to capital } \\
\text { for businesses } \\
\text { looking for } \\
\text { funding. }\end{array}$ & $\begin{array}{l}\text { Lenders and } \\
\text { referral partners } \\
\text { play an important } \\
\text { role in capital } \\
\text { provision and deal } \\
\text { flow origination. }\end{array}$ & $\begin{array}{l}\text { Fees and } \\
\text { interest on } \\
\text { loans. }\end{array}$ \\
\hline Hastee & $\begin{array}{l}\text { The mobile } \\
\text { application } \\
\text { provides direct } \\
\text { loans against } \\
\text { earned income to } \\
\text { individual users. }\end{array}$ & $\begin{array}{l}\text { The mobile platform } \\
\text { provides integration } \\
\text { with employers to } \\
\text { facilitate lending } \\
\text { application } \\
\text { approvals. }\end{array}$ & $\begin{array}{l}\text { The platform } \\
\text { supports } \\
\text { operational } \\
\text { workflow with } \\
\text { employers. }\end{array}$ & $\begin{array}{l}\text { The relationship } \\
\text { with Mastercard } \\
\text { allows for loan } \\
\text { withdrawals via } \\
\text { ATMs and other } \\
\text { transactions. }\end{array}$ & $\begin{array}{l}\text { Interest on } \\
\text { loans. }\end{array}$ \\
\hline $\begin{array}{l}\text { Wefox } \\
\text { Group }\end{array}$ & $\begin{array}{l}\text { Mobile } \\
\text { applications offer } \\
\text { insurance } \\
\text { purchasing and } \\
\text { claim management } \\
\text { directly to } \\
\text { consumers. }\end{array}$ & $\begin{array}{l}\text { The mobile platform } \\
\text { provides integration } \\
\text { with third-party } \\
\text { insurers to offer } \\
\text { different types of } \\
\text { insurance in one } \\
\text { application. }\end{array}$ & $\begin{array}{l}\text { The platform } \\
\text { streamlines } \\
\text { insurance related } \\
\text { workflow. }\end{array}$ & $\begin{array}{l}\text { The platform } \\
\text { enables the } \\
\text { insurance partner } \\
\text { workflow related to } \\
\text { purchase and claim } \\
\text { handling. }\end{array}$ & $\begin{array}{l}\text { Commission, } \\
\text { fees, interest } \\
\text { on insurance } \\
\text { services. }\end{array}$ \\
\hline Neyber & $\begin{array}{l}\text { The online } \\
\text { consumer lending } \\
\text { platform provides } \\
\text { direct access to } \\
\text { personal loans. }\end{array}$ & $\begin{array}{l}\text { The platform } \\
\text { streamlines credit } \\
\text { applications and it } \\
\text { operationalizes } \\
\text { credit underwriting } \\
\text { workflow. }\end{array}$ & $\begin{array}{l}\text { The mobile } \\
\text { platform is the } \\
\text { core asset } \\
\text { underpinning } \\
\text { operations. }\end{array}$ & $\begin{array}{l}\text { The platform } \\
\text { supports } \\
\text { relationships with } \\
\text { employers to } \\
\text { facilitate lending } \\
\text { against earned } \\
\text { income. }\end{array}$ & $\begin{array}{l}\text { Interest on } \\
\text { loans. }\end{array}$ \\
\hline SolarisBank & $\begin{array}{l}\text { The banking-as-a- } \\
\text { service platform is } \\
\text { offered to banks } \\
\text { and fintech } \\
\text { startups. }\end{array}$ & $\begin{array}{l}\text { The platform offers } \\
\text { digital banking, } \\
\text { digital cards, lending, } \\
\text { payments and know- } \\
\text { your-customer } \\
\text { services. }\end{array}$ & $\begin{array}{l}\text { The platform is } \\
\text { the key resource } \\
\text { that enables all } \\
\text { service delivery. }\end{array}$ & $\begin{array}{l}\text { The relationship } \\
\text { with Mastercard } \\
\text { provides access to } \\
\text { cross-institution } \\
\text { transfer services. }\end{array}$ & SaaS fees \\
\hline Rapyd & $\begin{array}{l}\text { A platform for } \\
\text { cross-border } \\
\text { payments directly } \\
\text { targets SMBs. }\end{array}$ & $\begin{array}{l}\text { The platform enables } \\
\text { all service aspects: } \\
\text { account setup and } \\
\text { management as well } \\
\text { as payment } \\
\text { acceptance. }\end{array}$ & $\begin{array}{l}\text { The platform is } \\
\text { the key resource } \\
\text { that enables all } \\
\text { service delivery. }\end{array}$ & $\begin{array}{l}\text { Partnerships with } \\
\text { Mastercard and } \\
\text { Visa allow Rapyd to } \\
\text { support global } \\
\text { money transfers } \\
\text { and cash } \\
\text { withdrawals across } \\
\text { the ATM networks. }\end{array}$ & $\begin{array}{l}\text { Transaction } \\
\text { fees }\end{array}$ \\
\hline Bancor & $\begin{array}{l}\text { Cryptocurrency } \\
\text { wallet targets } \\
\text { individual users } \\
\text { directly. }\end{array}$ & $\begin{array}{l}\text { The platform } \\
\text { facilitates } \\
\text { management and } \\
\text { exchange across } \\
\text { cryptocurrencies. }\end{array}$ & $\begin{array}{l}\text { The platform is } \\
\text { the key resource } \\
\text { that enables all } \\
\text { service delivery. }\end{array}$ & $\begin{array}{l}\text { Partnerships with } \\
\text { different } \\
\text { cryptocurrency } \\
\text { issuers and } \\
\text { cryptocurrency } \\
\text { exchanges facilitate } \\
\text { multiple } \\
\text { cryptocurrency } \\
\text { management and } \\
\text { trading. }\end{array}$ & $\begin{array}{l}\text { Transaction } \\
\text { fees }\end{array}$ \\
\hline Qonto & $\begin{array}{l}\text { The online } \\
\text { banking service } \\
\text { directly targets } \\
\text { freelancers and } \\
\text { SMBs. }\end{array}$ & $\begin{array}{l}\text { The platform } \\
\text { provides online } \\
\text { banking services for } \\
\text { SMBs. }\end{array}$ & $\begin{array}{l}\text { The platform is } \\
\text { the key resource } \\
\text { that enables all } \\
\text { service delivery. }\end{array}$ & $\begin{array}{l}\text { Tencent is a key } \\
\text { investor in Qonto } \\
\text { that provides the } \\
\text { company with } \\
\text { access to capital } \\
\text { and fintech } \\
\text { expertise. }\end{array}$ & $\begin{array}{l}\text { Transaction } \\
\text { fees }\end{array}$ \\
\hline
\end{tabular}




\section{Discussion}

\subsection{The contribution of IT to innovation in fintech}

Our analysis reveals that information technology plays a key role across all components of the business models in fintech firms. IT plays a central role in value creation and delivery across all firms in our sample. IT systems developed by the startups encompass business process logic that underpins the core value creation by the respective companies. This is the case for firms in the $\mathrm{B} 2 \mathrm{C}, \mathrm{B} 2 \mathrm{~B}$, and $\mathrm{B} 2 \mathrm{~B} / \mathrm{B} 2 \mathrm{C}$ startups, where the IT systems are the focal points of contact with customers. This is also the case in the $\mathrm{B} 2 \mathrm{~B} 2 \mathrm{~B}$ and $\mathrm{B} 2 \mathrm{~B} 2 \mathrm{C}$ scenarios where the systems integrate with partners to gain access to customers.

IT systems that are typically developed by startups as layered architectures with web and mobile frontend components, afford a direct channel to end customers. The direct route to end customers is consistent with the general role of technology in the disintermediation trend in fintech innovation that has been noted in prior research [5]. But the IT systems do more than just establish a direct route to end customers, the IT systems also support customer segmentation and personalization. The online banking and insurance startups are in a unique position to elicit individual customer preferences and provide service personalization for each individual client through automated segmentation and personalization algorithms.

Across all startups in our sample, the IT systems also perform a key resource and process coordination function. The systems encapsulate and automate business processes, e.g. account application processes, they also provide seamless integration with partner systems, where such integration is vital to service delivery, e.g. in the case of online banking and wire transfer services. By the virtue of encapsulating the core business processes and key partner relationships, the IT systems developed by fintech startups become the focal assets that support resource coordination that create value for the customers. In other words, information technology is interwoven into all elements of the fintech business models.

\subsection{Potential for disruptive innovation}

In his discussion of disruptive innovations, Christensen noted that disruptive innovations can emerge from low-cost offerings, focus on distinct customer segments, introduction of novel technologies and regulatory changes [6].
We find that twelve of thirteen startups (92.3\%) in our dataset focus on cost savings as the primary point of differentiation vis-à-vis traditional financial service providers. For example, the insurance marketplace offered by WeFox allows consumers to compare insurance offerings across multiple insurance providers and thus select the best option in terms of fit and price. The online banks in our sample offer free banking accounts and no ATM fees. This is in contrast with traditional banks that rely on account and ATM fees for a substantial part of their revenues [32]. Revolut offers free equity trading, undermining the traditional trading platform revenue model. Such offerings put pressure on the traditional revenue streams in financial services. Wall Street Journal reported erosion in the trading commission income across financial institutions offering equity trading that has been driven by online trading platforms offering free equity trading [21].

Focusing on innovations triggered by changes in regulation, we find two distinct subgroups of fintech startups in our sample. The first subgroup is comprised of online-only banks based in the UK. UK's efforts in encouraging financial innovation [2] appear to be paying off. We find six online-only banks based in the UK that have collectively raised over $\$ 2.6$ billion. These banks are continually expanding the range of services that they offer to consumers and SMBs. By the virtue of not having any branches, online banks have lower operating costs and can offer their services at lower price point vis-à-vis traditional banks.

Bancor exemplifies a case of novel financial services that emerged in response to regulatory changes. Cryptocurrencies have gained momentum in global adoption. TokenInsights reports that $\$ 13.8$ trillion worth of tokens were traded in spot exchanges in 2019 [35]. Whereas many countries have been hesitant to encourage token trading, Switzerland drafted national regulation that facilitates broader adoption of crypto-tokens [2]. Bancor capitalized on the unique new regulatory opportunities offered in Switzerland and the company has quickly emerged as a leading startup in cryptocurrency management.

\subsection{Contributions to theory and practice}

Our study makes a number of contributions to theory and practice. Our first theoretical contribution is in adapting and expanding the business model canvas framework to serve as an overarching theoretical lens for examining how IT contributes to innovation. The business model canvas has been lauded by practitioners as a useful lens in startup business model analysis [30] and entrepreneurship education as a useful pragmatic approach in teaching 
entrepreneurship [22]. However, the framework has a limitation in that it does not offer any testable propositions that limits its theoretical usefulness [20].

We expand the framework by focusing on the effects of technology across the framework components: value proposition, customer segments, distribution channels, key activities, resources, partners, and revenue stream. We find that at least in the context of fintech, IT fundamentally reshapes nearly all components of the business models vis-à-vis incumbent financial services business models. Our work provides the foundation for the examination of the IT effects on business model components in other contexts that can help identify contextual factors that can influence the scope of IT impact on the emergent business models enabled by IT in other industries.

Our second theoretical contribution is to the growing body of literature on digital innovation. Whereas prior research suggested that technology investments can lead to new product and service introduction among the incumbent firms [28] and theoretical discussions suggested that IT-enabled service innovation is fundamentally different from traditional innovation [29, 40], our study is among the first to empirically examine how IT technology contributes to innovation within startup business models. We find that leading startups in the European fintech ecosystem focus on leveraging technology to expand the availability of financial services, while delivering personalized experience to each customer. The startups streamline and automate business processes to achieve lower operating costs that they translate into lower cost offerings for their customers. These results highlight the potential transformative nature of IT in innovation.

Our results also have significant implications for practice. First, our analysis reveals that twelve of thirteen $(92.5 \%)$ of the startups in our sample offer lower-cost financial service alternatives vis-à-vis established financial institutions. Fintech services offered by startups may be initially incomplete in comparison to the full range of services offered by traditional financial institutions and therefore an objective assessment of the competitive threat posed by the startups may be underestimated by the incumbents. This is precisely the scenario that was highlighted by Christensen in his seminal work [7, 8]. Hence, our results suggest that the financial industry may be in the early stages of disruption that will likely undermine the incumbent business models.

Our results also have implications for regulators. We find that that UK's efforts in creating a regulatory environment to support fintech innovation is bearing fruit [2]. London has become the center of fintech innovation in Europe. Seven of thirteen startups
$(53.8 \%)$ in our sample are based in London. We also observe that Switzerland's efforts to make the country a preferred home for crypto-token related startups are also successful. These observations highlight the importance of regulation in supporting IT-enabled innovation.

\section{Conclusion}

Fintech is a rapidly growing area of practice that is expected to reach $\$ 300$ billion in revenues by 2023 [26], yet relatively little is known about how fintech startups leverage technology for innovation. To address this gap in research, we examined the leading startups in the European fintech ecosystem that have collectively raised over $\$ 5.2$ billion in funding. We drew on the business model canvas framework and we examined how the startups leverage technology across their business model components. We find that technology platforms form the core of the innovative service offerings developed by the startups in our dataset. Further, we find that startups use low-price offering as the dominant strategy for disrupting the existing financial services markets. We find that at least in the domain of fintech innovation, IT plays a central role as 1) customer facing artifact that supports personalization and 2) critical resource coordination mechanism. Our work lays the theoretical foundation for the examination of the effects of IT on business models across other contexts with the goal of elucidating contextual factors that can influence the scope of IT-driven disruptions across different industries.

\section{References}

[1] Amit, R., and C. Zott, "Creating value through business model innovation", MIT Sloan Management Review 53(3), 2012, pp. 41.

[2] Brummer, C., and D. Gorfine, "FinTech: Building a 21 st-century regulator's toolkit", Milken Institute 5, 2014. [3] CB Insights, "Venture Capital Funnel Shows Odds Of Becoming A Unicorn Are About 1\%", CB Research Briefs, 2018. https://www.cbinsights.com/research/venture-capitalfunnel-2/

[4] Chen, L., J.R. Marsden, and Z. Zhang, "Theory and Analysis of Company-Sponsored Value Co-Creation", Journal of Management Information Systems 29(2), 2012, pp. 141-172.

[5] Chiu, H., "Fintech and Disruptive Business Models in Financial Products, Intermediation and Markets- Policy Implications for Financial Regulators", Journal of Technology Law and Policy 21(1), 2016, pp. 55-112. [6] Christensen, C.M., "The innovator's dilemma: When new technologies cause great firms to fail Harvard Business School Press", Boston, MA, 1997.

[7] Christensen, C.M., The innovator's dilemma: when new 
technologies cause great firms to fail, Harvard Business Review Press, 2013.

[8] Christensen, C.M., T. Bartman, and D. van Bever, "The Hard Truth about Business Model Innovation", Sloan

Management Review 58(1), 2016, pp. 31-40.

[9] Crunchbase, "Crunchbase", 2019.

https://www.crunchbase.com/

[10] Eisenhardt, K.M., and Melissa E Graebner, "Theory building from cases: Opportunities and challenges",

Academy of Management Journal 50(1), 2007, pp. 25-32.

[11] Ernst and Young, "Who will disrupt the disruptors?", The Journal of Financial Perspectives 3(3), 2015, pp. 1191.

[12] Gai, K., M. Qiu, and X. Sun, “A survey on FinTech”, Journal of Network and Computer Applications 103(January 2017), 2018, pp. 262-273.

[13] Gassmann, O., E. Enkel, and H. Chesbrough, "The future of open innovation", $R \& D$ Management $40(3)$, 2010, pp. 213-221.

[14] Giot, P., and A. Schwienbacher, "IPOs, trade sales and liquidations: Modelling venture capital exits using survival analysis", Journal of Banking \& Finance 31(3), 2007, pp. 679-702.

[15] Glasser, B.G., and A.L. Strauss, "Theoretical Sampling.”, In N. Denzin, ed., Sociological Methods: A Sourcebook (Methodological Perspectives). Transaction Publishers, 2006, 106-114.

[16] Goldkuhl, G., "Pragmatism vs interpretivism in qualitative information systems research", European journal of information systems 21(2), 2012, pp. 135-146. [17] Gomber, P., R.J. Kauffman, C. Parker, and B.W. Weber, "On the Fintech Revolution: Interpreting the Forces of Innovation, Disruption, and Transformation in Financial Services", Journal of Management Information Systems 35(1), 2018, pp. 220-265.

[18] Gummesson, E., C. Mele, F. Polese, M. Galvagno, and D. Dalli, "Theory of value co-creation: a systematic literature review", Managing service quality 6, 2014, pp. 643-683.

[19] Den Hartigh, E., J.R. Ortt, G. Van de Kaa, and C.C.M. Stolwijk, "Platform control during battles for market dominance: The case of Apple versus IBM in the early personal computer industry", Technovation 48, 2016, pp. 4-12.

[20] Hong, Y.C., and C. Fauvel, "Criticisms, variations and experiences with business model canvas", 2013.

[21] Intelligent Investor, "Your Stock Trades Go Free but Your Cash Is in Chains", Wall Street Journal, 2019.

[22] Jackson, W.T., D.J. Scott, and N. Schwagler, "Using the business model canvas as a methods approach to teaching entrepreneurial finance", Journal of

Entrepreneurship Education 18(2), 2015, pp. 99.

[23] KPMG, Pulse of Fintech, 2020.

[24] Lee, I., and Y.J. Shin, "Fintech: Ecosystem, business models, investment decisions, and challenges", Business Horizons 61(1), 2018, pp. 35-46.

[25] Leong, C., B. Tan, X. Xiao, F.T.C. Tan, and Y. Sun, "Nurturing a FinTech ecosystem: The case of a youth microloan startup in China", International Journal of Information Management 37(2), 2017, pp. 92-97.

[26] MarketWatch, "Fintech Market: Industry Outlook,
Size \& Forecast 2018-2023”, MarketWatch, 2019. https://www.marketwatch.com/press-release/fintechmarket-industry-outlook-size-forecast-2018-2023-2019-0715

[27] Milian, E.Z., M. de M. Spinola, and M.M. de Carvalho, "Fintechs: A literature review and research agenda", Electronic Commerce Research and Applications 34, 2019, pp. 100833.

[28] Mithas, S., A. Tafti, I. Bardhan, and J.M. Goh, "Information technology and firm profitability: Mechanisms and empirical evidence", MIS Ouarterly 36(1), 2012, pp. 205-224.

[29] Nambisan, S., K. Lyytinen, A. Majchrzak, and M. Song, "Digital innovation management: reinventing innovation management research in a digital world.", $M I S$ Quarterly 41(1), 2017, pp. 223-238.

[30] Osterwalder, A., "The business model ontology a proposition in a design science approach", 2004.

[31] Philippon, T., "The FinTech Opportunity", NBR Working Papers 3(1), 2016, pp. 1-217.

[32] Radecki, L.J., Banks' payments-driven revenues, Federal Reserve Bank of New York, 2019.

[33] Reis, E., "The lean startup", New York: Crown Business, 2011, pp. 27.

[34] Szopinski, D., T. Schoormann, T. John, R. Knackstedt, and D. Kundisch, "Software tools for business model innovation: current state and future challenges", Electronic Markets, 2019, pp. 1-26.

[35] TokenInsight, 2019 Crypto Market Annual Report, 2020.

[36] Wade, M.R., "The Formation and value of IT-enable resources: Antecedents and consequences fo synergistic relationships", MIS Quarterly 34(1), 2010, pp. 163-183. [37] Weill, P., "The relationship between investment in information technology and firm performance: A study of the valve manufacturing sector", Information systems research 3(4), 1992, pp. 307-333.

[38] Williamson, J., "Bancor and the developing countries: how much difference would it have made?", In Keynes and Economic Development. Springer, 1987, 92-106.

[39] Yoo, Y., "The tables have turned: How can the information systems field contribute to technology and innovation management research?", Journal of the Association for Information Systems 14(5), 2012, pp. 4. [40] Yoo, Y., O. Henfridsson, and K. Lyytinen, "Research commentary - the new organizing logic of digital innovation: an agenda for information systems research", Information systems research 21(4), 2010, pp. 724-735. [41] Yu, D., and C.C. Hang, "A Reflective Review of Disruptive Innovation Theory", International Journal of Management Reviews 12(4), 2010, pp. 435-452.

[42] Zott, C., R. Amit, and L. Massa, "The business model: Recent developments and future research", Journal of Management 37(4), 2011, pp. 1019-1042. 